\title{
ガマ腫に対する舌下腺全摘出術の有用性
}

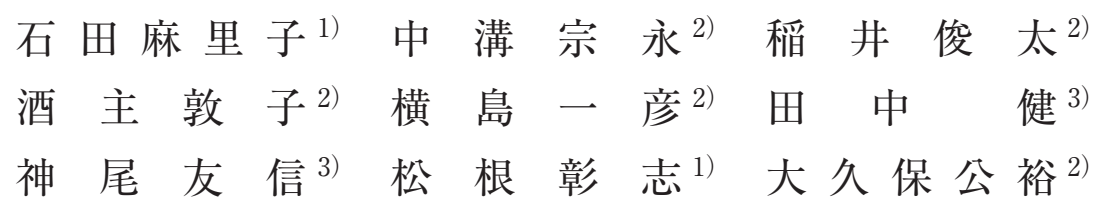

要旨: 舌下腺全摘出術を施行したガマ腫 17 例に対して, 前治療の有無, 手術時間, 術後在院日数, 再発の有 無を検討し, その有用性を考察した。性別は男 8 例, 女 9 例, 年齢は $8 \sim 51$ 歳 (中央値 26 歳)であった。手 術時間は $44 \sim 109$ 分 (中央值 70 分), 術後在院日数は $3 \sim 7$ 日（中央值 5 日）であった。 5 例に前治療歴があ り, 前治療の有無による術中・術後経過の差異は認めなかった。経過期間が 6 か月以上の症例は 15 例で, 経 過を確認し得た 14 例全例で再発を認めなかった。

本術式は, 進展範囲の大小や, 新鮮・再発例に関わらず 1 度の画一的な手術療法で完治が得られる可能性が 高く，有用な治療法と考えられた。

キーワード：ガマ腫, 舌下腺全摘出術, 手術成績, 傍咽頭間隙

\section{Summary Intraoral excision of the sublingual gland: an effective treatment for ranula:}

Mariko Ishida ${ }^{1)}$, Munenaga Nakamizo ${ }^{2}$, Shunta Inai ${ }^{2}$, Atsuko Sakanushi ${ }^{2}$, Kazuhiko Yokoshima ${ }^{2)}$, Ken Tanaka $^{3)}$, Tomonobu Kamio ${ }^{3)}$, Shoji Matsune ${ }^{1)}$ and Kimihiro Okubo ${ }^{2} .{ }^{1)}$ Department of Otorhinolaryngology, Nippon Medical School Musashikosugi Hospital, ${ }^{2}$ Department of Otorhinolaryngology and Head and Neck Surgery, Nippon Medical school Hospital, ${ }^{3)}$ Kamio Memorial Hospital

Based on the etiology of the ranula, intraoral excision of the sublingual gland is thought to be a recommended treatment for patients with ranula not only in terms of recovery but also for the prevention of recurrence after surgery. In recent years, we have treated these patients by intraoral excision of the ipsilateral sublingual glands. To evaluate the efficacy of this treatment, we clinically studied 17 cases with ranula, treated in our hospitals between January 2010 and December 2014. Eight were male and nine were female. The median age was 26 years and ranged from 8 to 51 years. Fourteen cases were plunging, and the other three cases were simple ranula. Median operation time was 70 minutes, ranging from 44 minutes to 109 minutes. Median duration of hospitalization after surgery was 5 days, ranging from 3 days to 7 days. Five cases $(29 \%)$ had a history of previous treatment by other than this modality. There were no differences in operation time or duration of hospitalization between cases with and without previous treatment. There were no long-term complications which influenced the duration of hospitalization. Recurrence was not detected in 14 cases in those we could follow up for more than 6 months, nor even in 2 cases with ipsilateral parapharyngeal space extension.

These results suggest that intraoral excision of the sublingual gland is an effective treatment for ranula.

Key words: ranula, intraoral excision of the sublingual gland, surgical results, parapharyngeal space

\footnotetext{
1) 日本医科大学武蔵小杉病院耳鼻咽喉科

2) 日本医科大学付属病院耳鼻咽喉科・頭頸部外科

3) 神尾記念病院

[平成 27 年 4 月 28 日受付, 平成 27 年 9 月 27 日受理]
} 


\section{はじめに}

ガマ腫は舌下間隙に限局する単純性ガマ腫（simple ranula）と, 単純性ガマ腫の壁の破綻とともに 舌下間隙をこえて形成された潜入性ガマ腫（plunging ranula）に分類される ${ }^{1)}$ が，いずれも，舌下腺 管・小唾液腺管の閉塞をもとにして生じる粘液貯留 囊胞である。その治療法には, 囊胞摘出術, 囊胞開 空術, 舌下腺全摘出術, OK- 432 囊胞内注入療法な どがあるが，成因を考えると舌下腺全摘出術が最も 理に適っているように思われる。そこで，当科では 最近 5 年間, 病型に関わらず舌下腺全摘出術を第一 選択の治療法として提示している。

本報告では, 患側の舌下腺全摘出術を施行したガ マ腫の手術所見, 治療効果を検討し, 本手術の有用 性を考察した。

\section{対 象}

2010 年 1 月から 2014 年 12 月までの 5 年間に, 当科で舌下腺全摘出術を施行した 17 例を対象にし た。

手術施行施設と症例数の内訳は, 日本医科大学付 属病院 9 例, 神尾記念病院 7 例, 日本医科大学武蔵 小杉病院 1 例であった。性別は男性 8 例, 女性 9 例 で, 年齢は 8 歳から 51 歳で, その中央值は 26 歳で あった。

\section{方法}

診断方法: 口腔底・頸部の視触診所見と画像診断 （CTもしくは MRI）に加え, 穿刺して得た蓑胞内 容物の性状を確認して診断した。

病型の分類は, 単純性ガマ腫（以下，舌下型） と, 顎下間隙に存在する潜入性ガマ腫を顎下型, 舌 下間隙・顎下間隙の両間隙にまたがるものを舌下 ・ 顎下型とした。

手術の手順：経鼻挿管で全身麻酔を維持し, アン グルワイダー, 万能開口器にて開口した後, 舌に絹 糸を通して星引し口腔底の視野を確保した。成書 2 の通り, 口腔底粘膜をメスで切開し, 舌下腺周囲を ツッペルで剥離し舌下腺を摘出した。ワルトン管と 舌神経を確認・温存し（図 1), 最後に口腔底を疎 に縫合した。ドレーンは挿入しなかった。また，囊 胞の穿刺排液や頸部圧迫処置も行わなかった。ガマ 腫の大小, 進展範囲に関わらず, 同一の術式を施行 した。術中のガマ腫の取り扱いに関しては, 視野の 妨げになる場合に囊胞壁を穿破し, 内容物を吸引除 去した。

検討方法：診療録から, 前治療の有無, 手術時

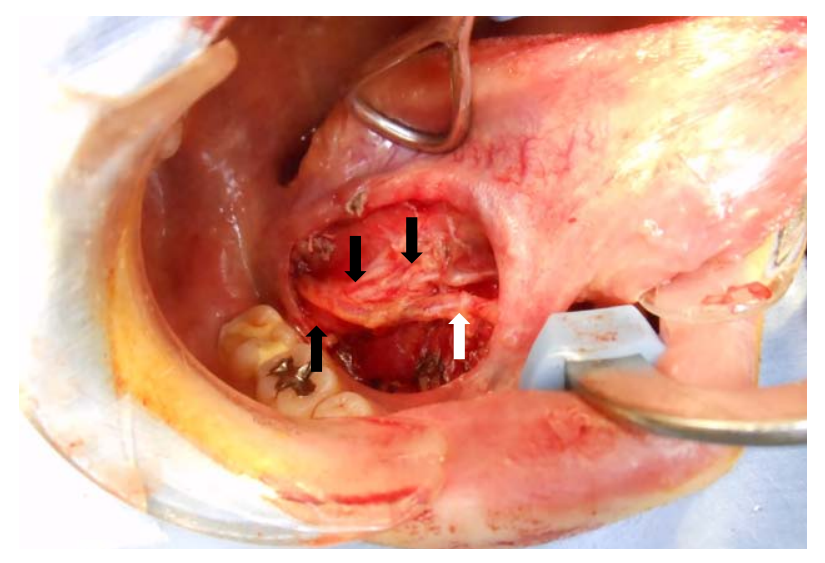

図 1 術中所見

舌下腺摘出後の状態。白矢印：ワルトン管, 黒矢印：舌神経。

間, 術後在院日数, 再発の有無を調查した。再発の 有無の確認は, 電話で 2015 年 2 月現在の腫脹の有 無を問い合わせて判断した。手術日から確認日まで の期間を経過期間とした。電話確認の取れなかった 症例に関しては, 手術日から最終受診日までを経過 期間とした。なお，前治療がない症例を新鮮例，前 治療がある症例を再発例とした。

\section{結 果}

全 17 例の臨床経過の調査結果を示した（表 1)。 3 例の MRI 画像所見 (T2 強調画像, 水平断 - 冠状 断）を提示した（図 2 図 4)。2 例で, 同側の傍咽 頭間隙に進展していた（図 3・図 4)。

病歴と前治療内容: 新鮮例は 12 例, 再発例が 5 例であった。

OK-432 囊胞内注入療法（以下 OK-432）単回が 2 例, OK- 432 複数回が 1 例, 頸部手術単回が 1 例, OK-432 単回と頸部手術複数回が 1 例であった。

手術時間と術後在院日数: 手術時間は 44 分から 109 分で, 中央値 70 分であった。最も時間を要し た症例は, 下顎骨外骨腫の処理を行って初めて, 口 腔底の視野が得られた症例であった。

術後の在院日数は 3 日から 7 日で, 中央值は 5 日 であった。

新鮮例と再発例での 2 群間の手術時間, 在院日数 を比較した。いずれも両群間に統計的な有意差を認 めなかった（Mann-Whitney U-test）。

術後経過と再発の有無: 経過期間は最短が 1 か月, 最長が 48 か月であった。

術後の短期的な副反応として, 1 例で術後に顎下 部腫脤が増悪した。手術翌日に顎下部穿刺し, 血性 貯留液が吸引された。1 例で顎下部腫脹が遷延した ため約 4 週間後に顎下部穿刺吸引を施行し, 血性貯 
表 1 ガマ腫 17 例の臨床経過

\begin{tabular}{|c|c|c|c|c|c|c|c|c|}
\hline $\begin{array}{l}\text { 症例 } \\
\text { 番号 }\end{array}$ & 年齢 & 性別 & 病型* & 前治療** & $\begin{array}{c}\text { 手術時間 } \\
\text { (分) }\end{array}$ & $\begin{array}{c}\text { 在院日数 } \\
(\text { 日) }\end{array}$ & $\begin{array}{c}\text { 経過期間**** } \\
\text { (月) }\end{array}$ & 再発** \\
\hline 1 & 26 & $\mathrm{~F}$ & SL & OK432 単 & 80 & 7 & 48 & - \\
\hline 2 & 21 & M & SM & OK432 単 & 78 & 5 & 1 & 未確認 \\
\hline 3 & 21 & M & $\mathrm{SM}$ & - & 83 & 4 & 39 & - \\
\hline 4 & 39 & M & SM & - & 62 & 3 & 39 & - \\
\hline 5 & 37 & M & $\mathrm{SM}$ & OK432 単·手術 3 回 & 70 & 7 & 12 & 未確認 \\
\hline 6 & 30 & M & $\mathrm{SM}$ & OK432 6 回 & 60 & 7 & 33 & - \\
\hline 7 & 30 & $\mathrm{~F}$ & $\mathrm{SM}$ & - & 83 & 7 & 33 & - \\
\hline 8 & 37 & $\mathrm{~F}$ & SL & - & 63 & 4 & 28 & - \\
\hline 9 & 9 & M & SM & - & 44 & 7 & 27 & - \\
\hline 10 & 19 & $\mathrm{~F}$ & SM & - & 60 & 5 & 24 & - \\
\hline 11 & 21 & $\mathrm{~F}$ & $\mathrm{SM}$ & - & 46 & 7 & 23 & - \\
\hline 12 & 11 & $\mathrm{M}$ & $\mathrm{SL} / \mathrm{SM}$ & - & 62 & 7 & 22 & - \\
\hline 13 & 35 & $\mathrm{~F}$ & SM & - & 84 & 5 & 11 & - \\
\hline 14 & 30 & $\mathrm{~F}$ & $\mathrm{SM}$ & - & 109 & 4 & 11 & - \\
\hline 15 & 51 & $\mathrm{~F}$ & $\mathrm{SM}$ & 手術 1 回 & 46 & 4 & 10 & - \\
\hline 16 & 24 & $\mathrm{M}$ & $\mathrm{SM}$ & - & 77 & 5 & 6 & - \\
\hline 17 & 8 & $\mathrm{~F}$ & SL & - & 84 & 4 & 2 & - \\
\hline
\end{tabular}

* : SL は舌下型, SM は顎下型, SL/SM は舌下・顎下型を表す。

**:「「」はなしを示す。

***：手術日から 2015 年 2 月末までの期間とした。日数は切り捨てた。症例 1,5 については手術日から最終 受診日までとした。

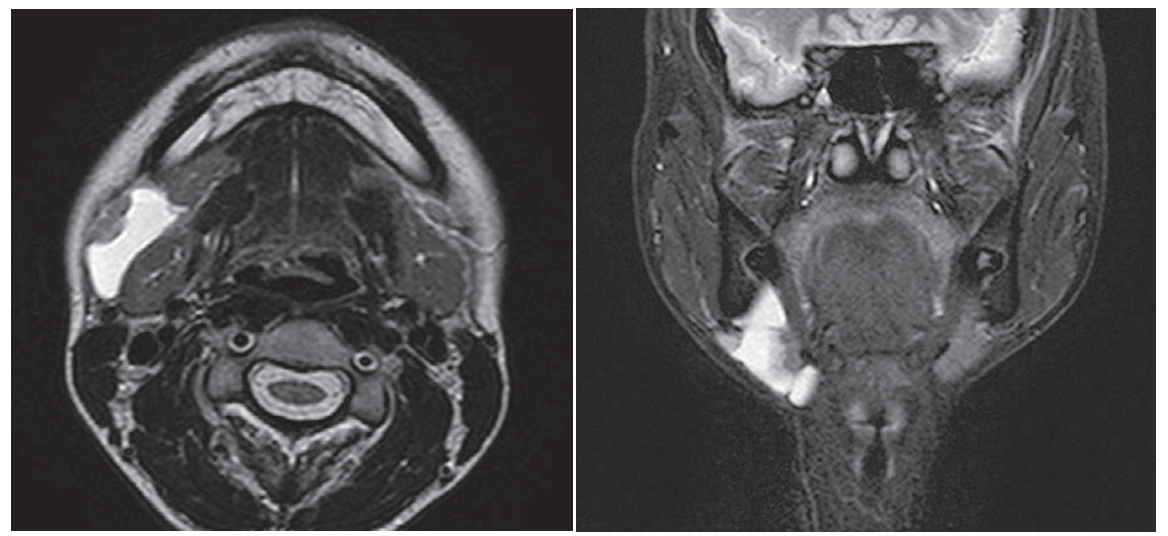

図 2 MRI 所見 (症例番号 14)

右顎下間隙を中心に囊胞性腫瘤を認め, 内側では舌下間隙後方にくちばし様 連続性が見られる。
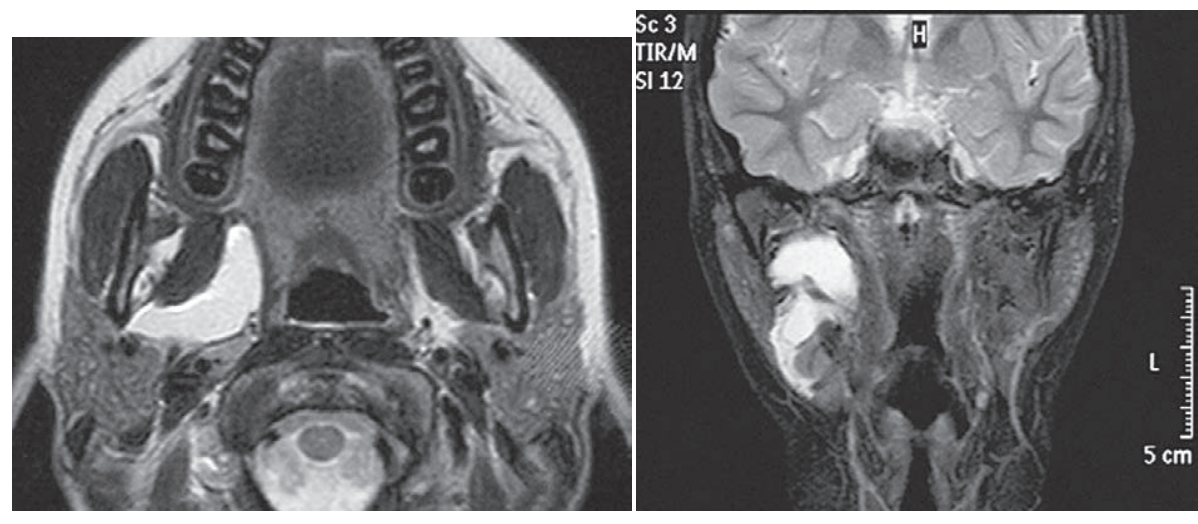

図 3 MRI 所見（症例番号 10）

右顎下間隙を中心に囊胞性腫瘤を認め，右傍咽頭間隙に進展を示す。 

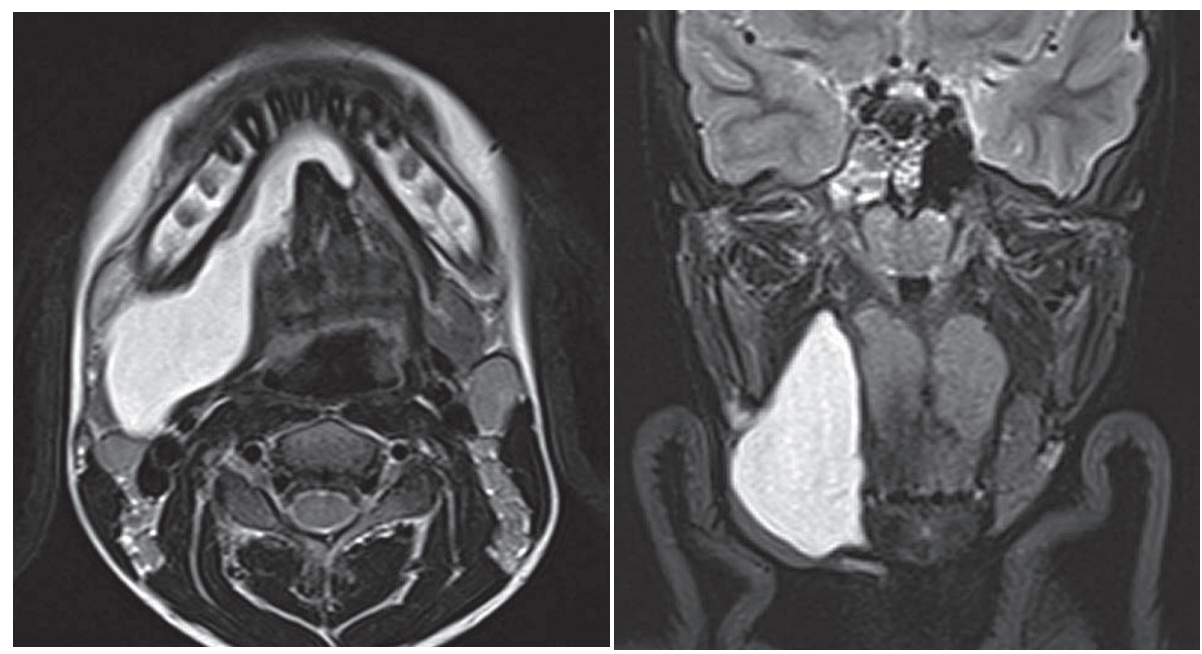

図 4 MRI 所見（症例番号 12）

右舌下間隙, 顎下間隙に囊胞性腫瘤を認め, 右舌下間隙から対側のオトガイ 舌筋の外側に進展している。上方へは右傍咽頭間隙に進展を示す。

表 2 舌下腺全摘出術の術後再発率

\begin{tabular}{|c|c|c|c|c|c|}
\hline \multirow{2}{*}{ 報告 } & \multirow{2}{*}{$\begin{array}{c}\text { 症例数 } \\
(\text { 例 })\end{array}$} & \multicolumn{2}{|c|}{ 病 型 } & \multirow{2}{*}{$\begin{array}{c}\text { 再発数 } \\
\text { (例) }\end{array}$} & \multirow{2}{*}{$\begin{array}{c}\text { 再発率 } \\
(\%)\end{array}$} \\
\hline & & 顎下型 & 舌下型 & & \\
\hline 南ら ${ }^{4)}$ & 32 & 25 & 7 & 0 & 0 \\
\hline 斉藤ら5) & 18 & 17 & 1 & 1 & 5.6 \\
\hline Zhao $5^{6)}$ & 415 & - & - & 5 & 1.2 \\
\hline 山田ら ${ }^{7)}$ & $\begin{array}{c}4 \\
\text { (小巟) }\end{array}$ & 3 & 1 & 0 & 0 \\
\hline 計良ら & 4 & 3 & 1 & 0 & 0 \\
\hline Yang $5^{9)}$ & 23 & 23 & 0 & 0 & 0 \\
\hline Zhi ら ${ }^{10)}$ & $\begin{array}{c}129 \\
\text { (小児) }\end{array}$ & 96 & 33 & 0 & 0 \\
\hline 自験例 & 14 & 12 & 2 & 0 & 0 \\
\hline
\end{tabular}

留液が吸引された。いずれの症例も腫脹は消失し, 再腫脹は認めなかった。長期的な副反応，合併症を 認めた症例はなかった。

経過期間が 6 か月以上の症例は 15 例で，そのう ち再発の有無を電話調査できた 14 例全例で再発を 認めなかった。

\section{考察}

ガマ腫の治療法には, 外来で局所麻酔下に施行で きる方法から，やや侵襲が大きく入院加療が必要な 治療法までが含まれる。治療目標が異なるため, 単 純な比較は困難であるが，ガマ腫が貯留囊胞である という成因を考えると, 舌下腺全摘出術が理に適っ た治療法であることが容易に理解できる2)。そこで, 最近われわれは，患者・家族へ治療法を説明する際 に，第一選択として舌下腺全摘出術を説明してき た。本報告では, その治療態度による成績を retro- spective に検証したものである。

本手術の手術時間は, 多くの症例で 1 時間程度で あった。また，在院期間は短期であった。7日間に 及んだ症例もあったが，周術期合併症で在院日数が 伸びた症例はなかった。3，4 日間の症例も複数あ り, それらの症例でも退院直後に問題を生じていな いことから, 今後はさらに在院日数の短縮が可能で あると思われた。一般的に, 再発例では舌下腺周囲 の症痕・瘉着のために対応が難しくなることが懸念 されが, 今回の手術時間と術後在院日数についての 解析結果からは, 再発例であっても手術に難渋する ことは少ないと考えられた。

顎下型ガマ腫の場合, 術中に顎下部の穿刺排液を 施行するかについて，当科ではこれまで自然吸収さ れると考えて施行していない。今回の検討では, 14 例中 2 例で術後に穿刺吸引処置を要した。術後反応 として, 顎下部に血液, 滲出液が溜まり, もともと 
あった唾液と混合した貯留液となったと考えられた。 顎下型ガマ腫に対して, 術中に顎下部穿刺吸引を施 行しているという報告 ${ }^{3)}$ があり, さらに術後の顎下 部圧迫固定の必要性については意見が分かれる4) が, 当科では術後経過観察において, 一過性に腫脤 が増悪する，もしくは腫脹が遷延する場合は顎下部 を穿刺吸引する対応をした。

再発に関しては, 確認し得た全例で再発を認めな かった。確認方法に正確さを欠く上, 短期間の経過 観察である症例も含まれているが, 治療短期（6か 月から 4 年）での再燃はないことが分かった。過去 の舌下腺全摘出術後の再発率（表 2）は $0 \sim 5.6 \%$ で, 他の治療法と比較して低率となっている ${ }^{4-10)}$ 。 今回の対象には自然治癒の可能性がある10) 小児例が 3 例含まれている。そのため, この結果が過大評価 になっている可能性がある。

ガマ腫の大きさや進展範囲による治療効果の限界 も興味深く, 今後の適応症例の判断をするに当たっ て有用な根拠になる。対象の中に 2 例で傍咽頭間隙 への進展を認めた（図 3 , 図 4)。われわれが渉猟し 得た報告は, 合計 20 例 ${ }^{11-16)}$ であり, 傍咽頭間隙進 展はまれとされている。そのため, 傍咽頭間隙に進 展するガマ腫の治療効果に関しては, 他の治療法と の比較も含め, 論議のあるところである。しかし自 験 2 例は型通りの舌下腺全摘出術で，それぞれ 2 年 以上経過した現在， 2 例とも再発を認めていない。

総括すると，ガマ腫に対する舌下腺全摘出術は, 1 度の入院手術で治療が完遂でき, 完治が得られる 可能性が高い。術後の後遺症や再発は認めず, 進展 範囲の大きい症例に対しても, 画一的な術式での治 療が可能と言える。他の治療後の再発例に対して も, 新鮮例と同様に手術施行でき, 術後経過に差異 はなかった。以上の点から, ガマ腫に対する舌下腺 全摘出術は有用な治療法と考えられた。

著者は申告すべき利益相反を有しない。

\section{文献}

1）尾尻博也：がま腫の画像所見と臨床. 耳鼻咽喉科展 望, $49: 255-257,2006$.

2) 市村恵一：ガマ腫. 耳鼻咽喉・頭頸部手術アトラス （下巻）（監修; 小松崎篤, 編集; 犬山征夫, 本庄 䉷, 森山 寛), 7-10, 医学書院, 東京, 2000.

3）野口雄五：がま腫の治療法の選択はどう考えるか? JOHNS, $24: 1531-1534,2008$.

4) 南 豊彦, 中川のぶ子, 井野千代徳, 他 : ガマ腫の 治療法としての舌下腺摘出術の位置付け。頭頸部外 科, $11: 49-52,2001$.

5) 斉藤輝海, 神野洋輔, 藤原成祥, 他 : ガマ腫 45 例の 臨床的検討. 愛院大歯誌, $40: 259-262,2002$.

6) Zhao Y, Jia Y, Chen X, et al: Clinical review of 580 ranulas. Oral Surg Oral Med Oral Pathol Oral Radiol Endod 98 : 281-287, 2004.

7）山田桂子, 砂川 元, 新崎 章, 他 : 小児のガマ腫 に関する臨床的検討. 小児口腔外科, $14: 18-22$, 2004.

8）計良 宗, 朝倉光司, 本間 朝, 他：ガマ腫 16 例の 臨床的検討. 耳鼻臨床, $103: 743-746,2010$.

9) Yang $Y$, Hong K: Surgical results of the intraoral approach for plunging ranula. Acta Oto-Laryngologica $134: 201-205,2014$.

10) Zhi K, Wen $Y$, Zhou H, et al: Management of the pediatric plunging ranula: result of 15 year's clinical experience. Oral Surg Oral Med Oral Pathol Oral Radiol Endod 107 : 499-502, 2009.

11) Kurabayashi $T$, Ida $M$, Yasumoto $M$, et al: MRI of ranulas. Neuroradiology $42: 917-922,2000$.

12) Macdonald A, Salzman K, Harnsberger H: Giant Ranula of the Neck: Differentiation from Cystic Hygroma. AJNR Am J Neuroradiol 24 : 757-761, 2003.

13) Ohta N, Fukase S, Suzuki Y, et al: OK-432 treatment of ranula extending to the parapharyngeal space. Acta Oto-Laryngologica 134 : 206-210, 2014.

14) Kim S, Huh K, An C, et al: Giant plunging ranula: a case report. Imaging Science in Dentistry $43: 55^{-}$ $58,2013$.

15) Kinoshita M, Kida W, Nakahara H: Plunging ranula intruding into the parapharyngeal space treated with OK-432. American Journal of OtolaryngologyHead and Neck Medicine and Surgery $33: 345^{-}$ 348, 2012.

16) Clyburn V, Smith J, Rumboldt T, et al: Ascending and plunging ranula in a pediatric patient. Otolaryngology-Head and Neck Surgery 140, 948-949, 2009 . 